\title{
A Systematic Review of the Clinical Use of Gabapentin and Pregabalin in Bipolar Disorder
}

\author{
Qin Xiang Ng ${ }^{1, *++}$, Ming Xuan Han ${ }^{2,+}{ }^{\circledR}$, Seth En Teoh ${ }^{3}$, Clyve Yu Leon Yaow ${ }^{3}$, Yu Liang Lim ${ }^{1}$ \\ and Kuan Tsee Chee ${ }^{4}$ \\ 1 MOH Holdings Pte Ltd., 1 Maritime Square, Singapore 099253, Singapore; yulianglim95@gmail.com \\ 2 Department of Community Emergency Health and Paramedic Practice, Monash University, \\ Clayton, VIC 3800, Australia; mxhan9598@yahoo.com \\ 3 Yong Loo Lin School of Medicine, National University of Singapore, 10 Medical Dr, \\ Singapore 117597, Singapore; e0659260@u.nus.edu (S.E.T.); e0268630@u.nus.edu (C.Y.L.Y.) \\ 4 Department of General and Community Psychiatry, Institute of Mental Health, 10 Buangkok View, \\ Buangkok Green, Medical Park, Singapore 539747, Singapore; kuan_tsee_chee@imh.com.sg \\ * Correspondence: ng.qin.xiang@u.nus.edu \\ + These authors contributed equally to this work.
}

check for updates

Citation: Ng, Q.X.; Han, M.X.; Teoh, S.E.; Yaow, C.Y.L.; Lim, Y.L.; Chee, K.T. A Systematic Review of the Clinical Use of Gabapentin and Pregabalin in Bipolar Disorder. Pharmaceuticals 2021, 14, 834. https: / / doi.org/10.3390/ph14090834

Academic Editor: Marek Krzystanek

Received: 2 August 2021

Accepted: 23 August 2021

Published: 24 August 2021

Publisher's Note: MDPI stays neutral with regard to jurisdictional claims in published maps and institutional affiliations.

Copyright: (c) 2021 by the authors. Licensee MDPI, Basel, Switzerland. This article is an open access article distributed under the terms and conditions of the Creative Commons Attribution (CC BY) license (https:// creativecommons.org/licenses/by/ $4.0 /)$.

\begin{abstract}
Despite its prevalence and disease burden, several chasms still exist with regard to the pharmacotherapy of bipolar disorder (BD). Polypharmacy is commonly encountered as a significant proportion of patients remain symptomatic, and the management of the depressive phase of the illness is a particular challenge. Gabapentin and pregabalin have often been prescribed off-label in spite of a paucity of evidence and clinical practice guidelines to support its use. This systematic review aimed to synthesize the available human clinical trials and inform evidence-based pharmacological approaches to BD management. A total of six randomized, controlled trials (RCTs) and 13 openlabel trials involving the use of gabapentin and pregabalin in BD patients were reviewed. Overall, the studies show that gabapentin and its related drug pregabalin do not have significant clinical efficacy as either monotherapy or adjunctive therapy for BD. Gabapentin and pregabalin are probably ineffective for acute mania based on the findings of RCT, with only small open-label trials to support its potential adjunctive role. However, its effects on the long-term outcomes of BD remain to be elucidated. The evidence base was significantly limited by the generally small sample sizes and the trials also had heterogeneous designs and generally high risk of bias.
\end{abstract}

Keywords: bipolar disorder; psychopharmacology; gabapentinoids; gabapentin; pregabalin

\section{Introduction}

Bipolar disorder (BD) is a debilitating mental illness that affects more than $1 \%$ of the world's population [1]. Its lifetime prevalence in adults across 11 countries was estimated to be $0.4 \%$ [2]. In adolescents, the prevalence rate increases to $3-4 \%$ [2], making it one of the main causes of disability among youth [1]. In most patients, the onset of cognitive and psychosocial decline begins often at an age younger than 30 years [3] and is characterized by symptoms of depression and mania (bipolar I) or depression and hypomania (bipolar II) $[1,3]$. This predisposes the individual with BD to a significantly higher risk of death by suicide [4], an unfortunate clinical outcome that remains a challenging and pertinent issue [5]. It has also been suggested that sensory processes unique to individuals are implicated in their corresponding emotional patterns, making BD a very heterogenous condition [6].

The heavy socioeconomic burden associated with BD cannot be underestimated. Costs per capita ranged from USD 4000 to 5000 for direct mental healthcare and from USD 8000 to 14,000 for overall direct healthcare [7]. In the United States alone, the total costs of bipolar I disorder were approximately USD 200 billion in 2015 [8]. 
Therapeutic measures for BD are unfortunately limited by the incomplete remission of symptoms and frequent relapses. The Systematic Treatment Enhancement Program for Bipolar Disorder (STEP-BD) study reported recurrence rates of more than $50 \%$ and recovery rates of lower than $60 \%$ [9]. There is a glaring paucity of treatment options for bipolar depression and a clear need for effective acute and maintenance treatments for all individuals with $\mathrm{BD}$, in order to delay illness progression, restore functioning and improve quality of life [10].

In modern clinical practice, patients generally are started on first-line BD medications and depending on symptom improvement and tolerability, either continued on the treatment regimen (with appropriate dose titration) or progressed to second-line medications. Alas, a combination of antipsychotics, mood stabilizers and other classes of psychotropic medications is often the choice in this challenging patient population, despite the inconsistent and scant evidence for polypharmacy [11].

With regard to pharmacotherapy, there has been sustained interest in the (off-label) use of gabapentin and its active metabolite, pregabalin in BD management. In patients with BD, the calcium pathway in intracellular secondary messaging of platelets is heightened [12], which suggests the involvement of calcium channels in BD pathophysiology. Pharmacodynamic evidence classifies gabapentin and pregabalin as ligands of the alpha2-delta subunit of voltage-gated calcium channels [13], and they have been reported to decrease neocortical noradrenaline release [14]. This inhibitory effect on calcium currents attenuates neurotransmitter release and subsequently reduces postsynaptic excitation [15]. While this mechanism of action has been reported in both rodent and human models, and across different pathological states (epilepsy, pain, anxiety) [14], evidence of efficacy for gabapentinoids in BD is still limited [16].

This systematic review hence endeavors to synthesize and elucidate all available evidence of gabapentin and pregabalin in the treatment of BD, thereby informing evidencebased pharmacological approaches to BD management.

\section{Methods}

This review protocol was guided by the latest Preferred Reporting Items for Systematic Reviews and Meta-Analyses (PRISMA) guidelines [17]. A systematic search strategy employing different combinations of the keywords (bipolar, mania, hypomania, gabapentin, neurontin, gralise, gabarone, fanatrex, pregabalin, lyrica) was developed and performed in five databases namely OVID Medline, PubMed, ProQuest, PsychInfo and ScienceDirect from database inception to 7 June 2021. A search of gray literature was also employed to maximize identification of articles of interest. Abstracts were imported into Covidence (Melbourne, Victoria, Australia) and screened by three independent researchers (Q.X.N., M.X.H., Y.L.L). Full-text articles were obtained for all abstracts of relevance and their respective reference lists hand-searched for references of interest. Forward searching of prospective citations of the relevant full texts was also performed and authors of the articles were contacted if necessary to provide additional data.

Full-text articles which were obtained for all relevant abstracts were reviewed by three researchers (Q.X.N., M.X.H., Y.L.L) for inclusion. Any disagreement was resolved by discussion and consensus. Studies were deemed eligible for inclusion based on the following criteria: (i) original published prospective clinical trial, (ii) patients were clinically diagnosed with bipolar disorder. Studies which were unpublished and not in English were excluded along with all case series, case reports, reviews, opinions and comments.

Data such as study design and population, clinical assessment tools, pharmacological interventions and key findings were extracted from all the studies reviewed and are summarized in Table 1. The quality and risk of bias of studies was assessed using the Cochrane Collaboration's tool for assessing risk of bias in randomized trials [18], and graded based on the consensus of three study investigators (Q.X.N., M.X.H., Y.L.L.). 
Table 1. Studies reviewed (arranged alphabetically by first author's last name).

\begin{tabular}{|c|c|c|c|c|c|}
\hline Author, Year & $\begin{array}{l}\text { Study Design } \\
\text { (N) }\end{array}$ & Study Population & $\begin{array}{c}\text { Clinical } \\
\text { Assessment or } \\
\text { Rating Tool(s) }\end{array}$ & Intervention(s) & Key Findings \\
\hline $\begin{array}{l}\text { Altshuleret } \\
\text { al., } 1999 \text { [16] }\end{array}$ & $\begin{array}{l}\text { Open-label } \\
\text { clinical trial } \\
\text { ( } n=28 \text { bipolar } \\
\text { patients) }\end{array}$ & $\begin{array}{l}\text { Patients had manic } \\
(n=18) \text {, depressive } \\
(n=5) \text { or rapid-cycling } \\
(n=5) \text { symptoms that } \\
\text { were unresponsive to at } \\
\text { least one mood } \\
\text { stabiliser. } \\
\text { Rapid-cycling patients } \\
\text { had treatment initiated } \\
\text { when they were } \\
\text { euthymic. Patients had } \\
\text { consultations with their } \\
\text { treating physicians } \\
\text { weekly to monthly. }\end{array}$ & $\begin{array}{l}\text { CGI-BP rated } \\
\text { every } 2 \text { weeks }\end{array}$ & $\begin{array}{l}\text { Gabapentin was given as an } \\
\text { adjunctive treatment, } \\
\text { added to an existing } \\
\text { medicine regimen. Doses } \\
\text { ranged from } 300 \text { to } \\
3600 \mathrm{mg} / \text { day for manic } \\
\text { symptoms, } 300 \text { to } \\
2400 \mathrm{mg} / \text { day for } \\
\text { depressive symptoms and } \\
600 \text { to } 3000 \mathrm{mg} / \text { day for } \\
\text { rapid-cycling patients. }\end{array}$ & $\begin{array}{l}-78 \%(n=18) \text { of patients treated } \\
\text { for manic symptoms had a } \\
\text { positive response to a dose } \\
\text { range of } 600 \text { to } 3600 \mathrm{mg} / \text { day } \\
\text { - Mean times to a recorded } \\
\text { positive response was } \\
12.7 \pm 7.2 \text { days for hypomania } \\
\text { patients, } 25 \pm 12 \text { days for } \\
\text { classic mania and } 31.8 \pm 20.9 \\
\text { days for mixed mania. } \\
\text { - All } 5 \text { patients treated for } \\
\text { depression had a positive } \\
\text { response in } 21 \pm 13.9 \text { days, } \\
\text { while only } 1 \text { patient in the } \\
\text { rapid-cycling group had a } \\
\text { positive response. } \\
-46 \%(n=12) \text { of patients had } \\
\text { reported side effects of sedation } \\
(n=5), \text { ataxia }(n=2), \text { dizziness } \\
(n=1) \text { and headache }(n=1)\end{array}$ \\
\hline $\begin{array}{l}\text { Astaneh } \\
\text { et al., } 2012 \\
\text { [17] }\end{array}$ & $\begin{array}{l}\text { Randomized, } \\
\text { open-label } \\
\text { clinical trial } \\
\text { ( } n=60 \text { bipolar } \\
\text { patients) }\end{array}$ & $\begin{array}{l}\text { Patients had a } \\
\text { diagnosis of bipolar } \\
\text { disorder and were } \\
\text { admitted in the acute } \\
\text { mania phase. }\end{array}$ & $\begin{array}{l}\text { YMRS rated at } \\
\text { the start and the } \\
\text { end of therapy }\end{array}$ & $\begin{array}{l}\text { Both groups were treated } \\
\text { with lithium for a period of } \\
6 \text { weeks. In the } \\
\text { experimental group, } \\
\text { gabapentin was given } \\
\text { adjunctively ( } 900 \mathrm{mg} \text { dose). }\end{array}$ & $\begin{array}{l}\text { - There was significant } \\
\text { improvement in the YMRS } \\
\text { score of the experimental group } \\
\text { as compared to the control } \\
\text { group. }\end{array}$ \\
\hline $\begin{array}{l}\text { Cabras et al., } \\
1999 \text { [18] }\end{array}$ & $\begin{array}{l}\text { Open-label } \\
\text { clinical trial } \\
(n=25 \\
\text { patients })\end{array}$ & $\begin{array}{l}\text { Patients were } 18 \text { years } \\
\text { and older, and had } \\
\text { diagnoses of bipolar I } \\
\text { disorder }(n=16) \text { or } \\
\text { schizoaffective disorder } \\
(n=9) \text { according to the } \\
\text { DSM-IV. Patients also } \\
\text { had to fulfill DSM-IV } \\
\text { criteria for episodes of } \\
\text { mania or hypomania. }\end{array}$ & $\begin{array}{l}\text { CGI-S and BPRS } \\
\text { evaluated at } \\
\text { baseline and } \\
\text { every } 2 \text { weeks. }\end{array}$ & $\begin{array}{l}\text { Treatment with gabapentin } \\
\text { was given over } 16 \text { weeks, } \\
\text { with other mood stabilisers } \\
\text { tapered off over a period of } \\
4 \text { weeks. Baseline } \\
\text { prescriptions of } \\
\text { benzodiazepines and } \\
\text { neuroleptics were } \\
\text { maintained. Gabapentin } \\
\text { was administered as an } \\
\text { initial dose of } 300 \mathrm{mg} \text { every } \\
\text { night, increased by } 300 \\
\text { mg/day every } 4 \text { days, } \\
\text { titrated to patient response } \\
\text { and tolerability (maximal } \\
\text { dose of } 2400 \mathrm{mg} / \text { day). }\end{array}$ & $\begin{array}{l}\text { - } 76 \% \text { of patients }(n=19) \text { had a } \\
\text { positive response measured by } \\
\text { the CGI and BPRS scores. } \\
\text { - CGI severity score decreased } \\
\text { from } 4.0 \pm 1.2 \text { at baseline to } \\
2.3 \pm 1.1 \text { at week } 16 \text {. The CGI } \\
\text { change score was statistically } \\
\text { significant }(\mathrm{t}=8.5, \mathrm{df}=21 \text {, } \\
p<0.0001) . \\
\text { - BPRS score decreased from } \\
29.1 \pm 7.1 \text { at baseline to } \\
21.3 \pm 3.3 \text { at week } 16 \text {. The BRPS } \\
\text { change score was statistically } \\
\text { significant }(\mathrm{t}=28.2, \mathrm{df}=11 \text {, } \\
p<0.0001) . \\
- \text { The mean dose was } 1440 \\
\text { mg/day with over-sedation } \\
\text { being the most common side } \\
\text { effect, as reported in } 44 \% \text { of } \\
\text { patients }(n=11) .\end{array}$ \\
\hline $\begin{array}{l}\text { Carta et al., } \\
2001 \text { [19] }\end{array}$ & $\begin{array}{l}\text { Open-label } \\
\text { clinical trial } \\
(n=10 \\
\text { patients })\end{array}$ & $\begin{array}{l}\text { Patients had } \\
\text { intellectual disability } \\
\text { (ID) with four mild } \\
\text { cases, five moderate } \\
\text { and one severe. All ten } \\
\text { patients had } \\
\text { concomitant bipolar } \\
\text { disorder }(n=6) \text { or } \\
\text { schizo-affective } \\
\text { disorder }(n=4) \text {. }\end{array}$ & $\begin{array}{l}\text { Assessment and } \\
\text { Information } \\
\text { Rating Profile } \\
\text { (AIRP) with the } \\
\text { psychopathology } \\
\text { section derived } \\
\text { from the } \\
\text { Psychopathology } \\
\text { Instrument for } \\
\text { Mentally } \\
\text { Retarded Adults } \\
\text { (PIMRA) }\end{array}$ & $\begin{array}{l}\text { Clinical observations were } \\
\text { performed during two } \\
\text { separate one-month } \\
\text { periods, E0 and E1. } \\
\text { Following E0, gabapentin } \\
\text { was administered } \\
\text { adjunctively with doses } \\
\text { ranging from } 600 \text { to } 900 \\
\text { mg/day. Mean treament } \\
\text { duration was four months. }\end{array}$ & $\begin{array}{l}\text { - In five patients with affective } \\
\text { disorders, there was a } \\
\text { statistically significant decrease } \\
\text { in total scores at E1 from E0, } \\
\text { with improvements recorded in } \\
\text { each scale of psychopathology. } \\
\text { - Overall scores were } 18.6 \pm 1.3 \\
\text { during E0 and } 10.2 \pm 5.8 \text { during } \\
\text { E1 (W }=15, p=0.05, \text { Wilcoxon's } \\
t \text {-test). } \\
\text { - The statistical significance was } \\
\text { only noted for subscales of } \\
\text { anxiety, depression and } \\
\text { adjustment disorders. }\end{array}$ \\
\hline
\end{tabular}


Table 1. Cont.

\begin{tabular}{|c|c|c|c|c|c|}
\hline Author, Year & Study Design & Study Population & \begin{tabular}{l}
\multicolumn{1}{c}{ Clinical } \\
Assessment or \\
Rating Tool(s)
\end{tabular} & Intervention(s) & Key Findings \\
\hline $\begin{array}{l}\text { Erfurth et al., } \\
1998 \text { [20] }\end{array}$ & $\begin{array}{l}\text { Open-label } \\
\text { trial }(n=14 \\
\text { patients) }\end{array}$ & $\begin{array}{l}\text { Patients met the } \\
\text { diagnostic criteria for } \\
\text { mania according to the } \\
\text { ICD-10. }\end{array}$ & $\begin{array}{l}\text { Bech-Rafaelsen } \\
\text { Mania Rating } \\
\text { Scale (BMRS) } \\
\text { assessed on days } \\
0,3,7,14 \text {, and } 21 \\
\text { by } 2 \text { trained } \\
\text { psychiatrists not } \\
\text { blind to the } \\
\text { treatment }\end{array}$ & $\begin{array}{l}\text { Gabapentin was given as } \\
\text { monotherapy for } 8 \text { patients } \\
\text { and adjunctively for } 6 \\
\text { patients for up to } 21 \text { days. } \\
\text { In the adjunctive group, the } \\
\text { existing medication had } \\
\text { been administered for a } \\
\text { minimum of } 14 \text { days } \\
\text { without a significant } \\
\text { improvement in manic } \\
\text { symptoms. Gabapentin } \\
\text { dose ranging from } 1200 \text { to } \\
4800 \text { mg/day. }\end{array}$ & $\begin{array}{l}\text { - Mean BMRS scores decreased } \\
\text { significantly from } 37.7 \text { to } 7.8 \text { in } \\
\text { the adjunctive group, and from } \\
27.8 \text { to } 9.0 \text { in four patients who } \\
\text { completed monotherapy. } \\
\text { - Mild sedation was reported as } \\
\text { a side-effect in the adjunctive } \\
\text { group ( } n=2) \text { who also had } \\
\text { concurrent increases in } \\
\text { pre-existing medication; may } \\
\text { not be due to gabapentin alone. }\end{array}$ \\
\hline $\begin{array}{l}\text { Frye et al., } \\
2000 \text { [21] }\end{array}$ & $\begin{array}{l}\text { Double-blind, } \\
\text { randomised, } \\
\text { crossover trial } \\
\text { ( } n=31 \\
\text { patients) }\end{array}$ & $\begin{array}{l}\text { Patients comprised } \\
18 \text { women and } 13 \text { men, } \\
\text { with bipolar I }(n=11) \\
\text { and bipolar II }(n=14) \\
\text { disorder. } 23 \text { had } \\
\text { rapid-cycling } \\
\text { symptoms while } 6 \text { were } \\
\text { unipolar patients. }\end{array}$ & $\begin{array}{l}\text { CGI-BP, HAM-D, } \\
\text { STAI, YMRS and } \\
\text { BPRS }\end{array}$ & $\begin{array}{l}\text { Gabapentin was given as an } \\
\text { initial dose of } 900 \mathrm{mg} / \text { day } \\
\text { and increased to } 1500 \\
\text { mg/day, } 2700 \mathrm{mg} / \text { day, } \\
3600 \mathrm{mg} / \text { day, } 4200 \mathrm{mg} / \text { day } \\
\text { and } 4800 \mathrm{mg} \text { /day by the } \\
\text { end of the first, second, } \\
\text { third, fourth and fifth to } \\
\text { sixth weeks, respectively. } \\
\text { Patients received 3 } \\
\text { treatments (gabapentin, } \\
\text { lamotrigine and placebo) } \\
\text { sequentially over three } \\
\text { 6-week phases with an } \\
\text { approximate crossover } \\
\text { period of one week } \\
\text { between phases. }\end{array}$ & $\begin{array}{l}\text { - } 26 \% \text { of patients }(8 / 31) \text { had } \\
\text { positive response rates as } \\
\text { denoted by the overall CGI } \\
\text { rating after gabapentin } \\
\text { administration. } \\
\text { - The gabapentin response rates } \\
\text { for mania and depression were } \\
20 \%(5 / 25) \text { and } 26 \%(8 / 31) \text {, } \\
\text { respectively. } \\
\text { - Common side effects } \\
\text { post-gabapentin administration } \\
\text { were ataxia }(n=3), \text { diarrhoea } \\
(n=2) \text {, diplopia }(n=3), \text { fatigue } \\
(n=3) \text { and headache }(n=4) \text {. }\end{array}$ \\
\hline $\begin{array}{l}\text { Mauri et al., } \\
2001 \text { [22] }\end{array}$ & $\begin{array}{l}\text { Open-label } \\
\text { trial }(n=21 \\
\text { patients) }\end{array}$ & $\begin{array}{l}\text { There were } 21 \\
\text { outpatients comprising } \\
13 \text { females and } 8 \text { males. } \\
\text { Patients were } \\
\text { diagnosed with bipolar } \\
\text { types I and II } \\
\text { (according to DSM-IV) } \\
\text { and were assessed to be } \\
\text { in partial remission. } \\
\text { Patients were all } \\
\text { intolerant and } \\
\text { noncompliant with } \\
\text { lithium. }\end{array}$ & $\begin{array}{l}\text { BPRS, HAM-D, } \\
\text { HAM-A and } \\
\text { Manic Rating } \\
\text { Scale (MRS) were } \\
\text { assessed at } \\
\text { baseline, days } 15, \\
30 \text { and then } \\
\text { monthly up to } \\
12 \text { months }\end{array}$ & $\begin{array}{l}\text { Gabapentin was } \\
\text { administered at doses } \\
\text { ranging from } 300 \text { to } 2400 \\
\text { mg/day for a period of } 1 \\
\text { year. } 2 \text { weeks prior to the } \\
\text { start of the interventions, } \\
\text { all anticonvulsants were } \\
\text { ceased, with } \\
\text { benzodiazepines used only } \\
\text { if necessary. }\end{array}$ & $\begin{array}{l}\text { - Over the one year study } \\
\text { period, no significant } \\
\text { differences in HAM-D, HAM-A } \\
\text { and MRS scores were found. } \\
\text { - There was a significant } \\
\text { decrease recorded for the mean } \\
\text { BPRS scores. } \\
\text { - A negative correlation was } \\
\text { determined between the dose of } \\
\text { gabapentin administered and } \\
\text { HAM-A scores ( }=0.16 \text {, } \\
p=0.035 \text { ) but no relationship } \\
\text { was found with the mean scores } \\
\text { of BPRS, HAM-D and MRS. } \\
\text { - No relationship between } \\
\text { adverse events and gabapentin } \\
\text { dose (mg/kg) observed. }\end{array}$ \\
\hline $\begin{array}{l}\text { McElroy } \\
\text { et al., } 1997 \\
{[23]}\end{array}$ & $\begin{array}{l}\text { Open-label, } \\
\text { prospective } \\
\text { trial }(n=9 \\
\text { patients })\end{array}$ & $\begin{array}{l}\text { Patients were } 18 \text { years } \\
\text { and older; diagnosed } \\
\text { with either bipolar I } \\
(n=7) \text { or II }(n=2) \\
\text { according to DSM-IV; } \\
\text { did not show adequate } \\
\text { response to lithium, } \\
\text { valproate or } \\
\text { carbamazepine; had } \\
\text { symptoms of } \\
\text { hypomania, mania or } \\
\text { mixed states }\end{array}$ & $\begin{array}{l}\text { Treatment } \\
\text { response was } \\
\text { evaluated } \\
\text { monthly } \\
\text { according to this } \\
\text { scale: } 0 \text { (no } \\
\text { response or } \\
\text { worsening), } \\
1 \text { (minimal } \\
\text { improvement), } \\
2 \text { (moderate } \\
\text { improvement) } \\
\text { and } 3 \text { (marked } \\
\text { improvement). }\end{array}$ & $\begin{array}{l}\text { Gabapentin was } \\
\text { administered adjunctively } \\
\text { as an initial dose of } 300 \text { to } \\
900 \mathrm{mg} / \text { day, and increased } \\
\text { by } 300 \text { to } 900 \mathrm{mg} \text { /day every } \\
\text { three to } 14 \text { days (titrated to } \\
\text { side effects). The maximum } \\
\text { dose was } 4800 \mathrm{mg} / \text { day. }\end{array}$ & $\begin{array}{l}\text { - Seven out of nine patients } \\
\text { displayed moderate or marked } \\
\text { improvements in symptoms of } \\
\text { mania after } 1 \text { month of } \\
\text { adjunctive gabapentin } \\
\text { treatment. } \\
\text { - This increased to eight patients } \\
\text { after three months of treatment. } \\
\text { - Common side effects were } \\
\text { sedation }(n=7) \text {, forgetfulness } \\
(n=3) \text { and ataxia }(n=2) \text {. }\end{array}$ \\
\hline
\end{tabular}


Table 1. Cont.

\begin{tabular}{|c|c|c|c|c|}
\hline Author, Year & $\begin{array}{c}\text { Study Design } \\
(\mathbf{N})\end{array}$ & Study Population & $\begin{array}{l}\text { Clinical } \\
\text { Assessment or } \\
\text { Rating Tool(s) }\end{array}$ & Intervention(s) \\
\hline $\begin{array}{l}\text { Mokhber } \\
\text { et al., } 2008 \\
{[24]}\end{array}$ & $\begin{array}{l}\text { Double-blind, } \\
\text { fixed dose, } \\
\text { randomised } \\
\text { clinical trial } \\
(n=59)\end{array}$ & $\begin{array}{l}\text { Patients comprised } 28 \\
\text { women and } 3 \text { men; age } \\
\text { range between } 18 \text { to } 60 \\
\text { years; diagnosed with } \\
\text { dysphoric mania by } \\
\text { DSM-IV; had history of } \\
\text { bipolar I disorder with } \\
\text { at least one episode of } \\
\text { mania prior and a } \\
\text { recent episode of } \\
\text { mixed mania }\end{array}$ & $\begin{array}{l}\text { Minnesota } \\
\text { Multiphasic } \\
\text { Personality } \\
\text { Inventory } 2 \\
\text { (MMPI-2) } \\
\text { evaluated at } \\
\text { baseline and final } \\
\text { visit }\end{array}$ & $\begin{array}{l}\text { Randomisation was } \\
\text { performed yielding } 3 \\
\text { experimental groups } \\
\text { - Group } 1(n=18) \text { : } \\
\text { gabapentin } 900 \mathrm{mg} / \text { day } \\
\text { - Group } 2(n=20): \\
\text { lamotrigine } 100 \mathrm{mg} / \text { day } \\
\text { - Group } 3(n=13) \text { : } \\
\text { carbamazepine } 600 \mathrm{mg} / \text { day }\end{array}$ \\
\hline
\end{tabular}

mixed mania

- There was a significant decrease of $50 \%(p<0.000)$ in MMPI-2 scores for depression for the group administered with gabapentin. This decrease was higher than the lamotrigine group (33\% decrease) and carbamazepine group (13\% decrease).

- Similarly, a significant decrease of $75 \%$ was recorded for the MMPI-2 scores for mania in the gabapentin group. This decrease was higher than the lamotrigine and cabamazepine groups which had reductions of $64 \%$ and $59 \%$, respectively.

- Response rates according to overall CGI-BP were 20/39 $(51 \%), 11 / 40(28 \%)$, and $8 / 38$ $(21 \%)$ for patients who were administered lamotrigine, gabapentin, and placebo, respectively.

Gabapentin was administered at a

35 patients with refractory bipolar affective disorder and

Obrocea et al., 2002

Double-blind,

10 patients with

three-way,

randomized

trial $(n=45)$ refractory unipola

affective disorder were

recruited in the clinical study, of which there

were 27 women and

18 men.
CGI-BP, HAM-D, clinician and self prospective life chart methodology (LCM), YMRS, STAI and

Bunney-

Hamburg ratings of depression and mania maximum dose of $4800 \mathrm{mg}$

for 6 weeks with a 1 week interval between two subsequent crossovers to the other agents.

Lamotrigine (maximum dose of $500 \mathrm{mg}$ ) and placebo (equal number of pills to the other drugs) were also administered for the same duration as that of gabapentin.

- Younger patients responded better than older patients when gabapentin was administered $(\mathrm{r}=-0.37 ; p=0.19)$

- Patients who had a longer duration of illness responded more poorly than patients who had a shorter duration of illness $(\mathrm{r}=-0.35 ; p=0.19)$

- Patients who were lighter in weight before the trial responded better to gabapentin than those who were initially heavier $(\mathrm{r}=-0.44 ; p=0.006)$. - Patients over the age of 45 years and over $95 \mathrm{~kg}$ in weight responded poorly to gabapentin, and some patients displayed

worsening symptoms.

Study cohort

comprised outpatients who were diagnosed with bipolar 1 disorder based on DSM-IV criteria, with

Double-blind,

Pande et al., placebo2000 [26] controlled $\operatorname{trial}(n=117)$ manic/hypomanic or mixed symptoms. All included patients had to meet the criteria for a lifetime diagnosis of bipolar I and score of more than or equal to 12 on the YMRS at the first clinic visit.
58 patients were

YMRS, HAM-D, administered gabapentin HAM-A, CGI-C, three times a day of a Internal state scale (ISS), and Life Chart for Recurrent Affective Illness dosage ranging from 600 to $3600 \mathrm{mg} /$ day for 10 weeks, while 59 patients were administered a placebo for the same duration.
- Both treatment groups (gabapentin and placebo) displayed decreased total YMRS scores from baseline to endpoint but this decrease was significantly lower in the gabapentin group $(-6)$ than the placebo group $(-9)(p<0.05)$ - No difference between treatments were observed for the total score on HAM-D - Secondary efficacy measures were similar between the two treatment groups. 
Table 1. Cont.

\begin{tabular}{|c|c|c|c|c|c|}
\hline Author, Year & $\begin{array}{l}\text { Study Design } \\
(\mathbf{N})\end{array}$ & Study Population & $\begin{array}{l}\text { Clinical } \\
\text { Assessment or } \\
\text { Rating Tool(s) }\end{array}$ & Intervention(s) & Key Findings \\
\hline $\begin{array}{l}\text { Perugi et al., } \\
1999 \text { [27] }\end{array}$ & $\begin{array}{l}\text { Open-label } \\
\text { trial }(n=21)\end{array}$ & $\begin{array}{l}\text { Study cohort } \\
\text { comprised patients } \\
\text { diagnosed with bipolar } \\
\text { type I mixed episodes, } \\
\text { based on DSM-III-R } \\
\text { criteria. Included } \\
\text { patients were resistant } \\
\text { to therapeutic levels of } \\
\text { standard mood } \\
\text { stabilizers and the } \\
\text { semistructured } \\
\text { interview for mood } \\
\text { disorder (SIMD) was } \\
\text { utilized to ensure that } \\
\text { the diagnostic criteria } \\
\text { were satisfied. }\end{array}$ & $\begin{array}{l}\text { HAM-D, YMRS } \\
\text { and CGI-C }\end{array}$ & $\begin{array}{l}\text { Gabapentin was } \\
\text { administered adjunctively } \\
\text { starting with an initial } \\
\text { dosage of } 300 \mathrm{mg} / \text { day } \\
\text { which was subsequently } \\
\text { increased to } 2000 \mathrm{mg} / \text { day } \\
\text { based on the clinical } \\
\text { response and occurrence of } \\
\text { any significant side effects. } \\
\text { The mean (+/ - SD) dose of } \\
\text { gabapentin at week } 8 \text { was } \\
1130+/-361.4 \text { mg (range } \\
600 \text { to } 2000 \mathrm{mg} \text { ). }\end{array}$ & $\begin{array}{l}\text { - Out of the } 20 \text { patients who } \\
\text { completed the } 8 \text { weeks of } \\
\text { therapy, } 10 \text { were regarded as } \\
\text { responders: } 4 \text { with a CGI score } \\
\text { of } 1 \text { (marked improvement) and } \\
6 \text { with a CGI score of } 2 \\
\text { (moderate improvement); } 9 \\
\text { patients were regarded as } \\
\text { nonresponders: } 7 \text { with a CGI } \\
\text { score of } 3 \text { (minimum } \\
\text { improvement) and } 2 \text { with a CGI } \\
\text { score of } 4 \text { (no change). } \\
\text { - } 9 \text { of the } 10 \text { responders } \\
\text { maintained symptomatic } \\
\text { remission over a } 4 \text { to } 12 \text { month } \\
\text { period, without adverse effects. } \\
\text { - Mean final CGI score for all } \\
\text { patients (responders and } \\
\text { nonresponders) was } 3.7+1.1 \text {. } \\
\text { - Mean HRSD score showed a } \\
\text { statistically significant decrease } \\
\text { from } 18.2 \text { to } 10.6 \text { (t }=5.73 \text {; } \\
p<0.0001 \text { ). }\end{array}$ \\
\hline $\begin{array}{l}\text { Perugi et al., } \\
2002 \text { [28] }\end{array}$ & $\begin{array}{l}\text { Open-label } \\
\text { trial }(n=43)\end{array}$ & $\begin{array}{l}\text { Study cohort } \\
\text { comprised patients } \\
\text { diagnosed with bipolar } \\
\text { disorder and current } \\
\text { major depression } \\
(n=14) \text {, mixed state } \\
(n=24) \text {, or a manic } \\
\text { episode }(n=5) \text {, based } \\
\text { on the DSM-III-R } \\
\text { criteria. The SIMD was } \\
\text { utilized to ensure that } \\
\text { the diagnostic criteria } \\
\text { were met. }\end{array}$ & $\begin{array}{l}\text { HAM-D, YMRS } \\
\text { and CGI-C }\end{array}$ & $\begin{array}{l}\text { Gabapentin was given as an } \\
\text { add-on therapy with other } \\
\text { mood stabilizers for } 8 \\
\text { weeks. The initial dosage of } \\
\text { gabapentin administered } \\
\text { was } 300 \mathrm{mg} / \text { day which was } \\
\text { subsequently increased to } \\
2400 \mathrm{mg} \text { / day based on the } \\
\text { clinical response and } \\
\text { occurrence of any } \\
\text { significant side effects. The } \\
\text { mean (+/-SD) dose of } \\
\text { gabapentin at week } 8 \text { was } \\
1272+/-465.13 \text { mg (range } \\
600 \text { to } 2400 \mathrm{mg} \text { ). }\end{array}$ & $\begin{array}{l}\text { - } 18 \text { patients out of the study } \\
\text { cohort were considered } \\
\text { responders; } 8 \text { had a CGI score } \\
\text { of } 1 \text { and } 10 \text { had a CGI score of } 2 \text {. } \\
\text { - } 22 \text { patients out of the study } \\
\text { cohort were considered } \\
\text { non-responders; } 15 \text { had a CGI } \\
\text { score of } 3,5 \text { had a CGI score of } \\
4 \text {, while } 5 \text { had a CGI score of } 5 \text {. } \\
\text { - Mean total HAM-D score } \\
\text { showed statistically significant } \\
\text { reduction during the } 8 \text { weeks of } \\
\text { treatment from } 16.0 \text { to } 8.4 \\
\text { ( } t=4.51, p>0.05) \text {. } \\
\text { - Mean total YMRS score did not } \\
\text { show a statistically significant } \\
\text { reduction ( } \mathrm{t}=1.60, p>0.05) \text {. } \\
\text { - } 17 \text { out of the } 18 \text { patients } \\
\text { deemed as responders } \\
\text { maintained symptomatic } \\
\text { remission over a period of } 4 \text { to } \\
18 \text { months, without side effects. }\end{array}$ \\
\hline $\begin{array}{l}\text { Schaffer } \\
\text { et al., } 2013 \\
\text { [29] }\end{array}$ & $\begin{array}{l}\text { Open-label } \\
\text { study }(n=58)\end{array}$ & $\begin{array}{l}\text { All patients ( } 46 \text { females } \\
\text { and } 12 \text { males; mean age } \\
47 \text { years) were } \\
\text { outpatients at a private } \\
\text { practice and satisfied } \\
\text { the DSM-IV diagnostic } \\
\text { criteria for bipolar } \\
\text { disorder.Patients were } \\
\text { administered } \\
\text { pregabalin as an } \\
\text { add-on therapy if they } \\
\text { were deemed to be } \\
\text { nonresponders or } \\
\text { unsatisfactory partial } \\
\text { responders to majority } \\
\text { of the standard } \\
\text { medications for } \\
\text { bipolar disorder. }\end{array}$ & CGI-BP & $\begin{array}{l}\text { The average dose }(+/-\mathrm{SD}) \\
\text { of pregabalin for acute } \\
\text { responders was } 72 \mathrm{mg} \\
(+/-69) . \text { The average dose } \\
(+/-\mathrm{SD}) \text { of pregabalin for } \\
\text { non-responders was } 84 \mathrm{mg} \\
(+/-74) . \text { The average dose } \\
(+/-\mathrm{SD}) \text { of pregabalin for } \\
\text { patients on maintenance } \\
\text { therapy was } 90 \mathrm{mg} \\
(+/-67.9) .\end{array}$ & $\begin{array}{l}\text { - } 24 / 58 \text { patients were deemed } \\
\text { as acute responders to } \\
\text { pregabalin, of which } 12 \\
\text { experienced a mood stabilizing } \\
\text { effect of either mixed or rapid } \\
\text { cycling symptoms; } 5 \\
\text { experienced an antimanic effect; } \\
7 \text { experienced an antidepressant } \\
\text { effect. } \\
\text { - } 10 \text { of these } 24 \text { patients were } \\
\text { still taking pregabalin as an } \\
\text { adjunctive therapy for a mean } \\
\text { of } 45.2 \text { months (range } 42-48 \text {; } \\
\text { SD: } 2.35 \text { ). }\end{array}$ \\
\hline
\end{tabular}


Table 1. Cont.

\begin{tabular}{|c|c|c|c|c|c|}
\hline Author, Year & $\begin{array}{l}\text { Study Design } \\
\text { (N) }\end{array}$ & Study Population & $\begin{array}{c}\text { Clinical } \\
\text { Assessment or } \\
\text { Rating Tool(s) }\end{array}$ & Intervention(s) & Key Findings \\
\hline $\begin{array}{l}\text { Sokolski } \\
\text { et al., } 1999 \\
\text { [30] }\end{array}$ & $\begin{array}{l}\text { Open-label } \\
\text { trial }(n=10)\end{array}$ & $\begin{array}{l}\text { Outpatients ( } 9 \text { males } \\
\text { and } 1 \text { female, mean age } \\
50.4 \text { years), diagnosed } \\
\text { with Bipolar I by SCID. } \\
\text { None were psychotic at } \\
\text { entry. Previously } \\
\text { received therapeutic } \\
\text { dosages of mood } \\
\text { stabilizers for at least } 2 \\
\text { months with partial } \\
\text { responses. }\end{array}$ & $\begin{array}{l}\text { HAM-D and } \\
\text { Bech Mania } \\
\text { Rating Scales } \\
\text { (BMRS) }\end{array}$ & $\begin{array}{l}\text { Adjunctive gabapentin } 300 \\
\text { mg initially, increased by } \\
600 \text { mg a week until } \\
\text { patients reported a full } \\
\text { night sleep or could no } \\
\text { longer tolerate sedative } \\
\text { side effects. Study duration } \\
\text { was } 10 \text { weeks. }\end{array}$ & $\begin{array}{l}\text { - Adjunctive gabapentin } \\
\text { decreased HAM-D and Bech } \\
\text { mania rating scores as early as } \\
\text { after the first week of study, and } \\
\text { the effects were sustained. } \\
\text { - Common side effects include } \\
\text { somnolence, dizziness and poor } \\
\text { coordination, otherwise } \\
\text { well-tolerated. }\end{array}$ \\
\hline $\begin{array}{l}\text { Vieta et al., } \\
2000 \text { [31] }\end{array}$ & $\begin{array}{l}\text { Open-label } \\
\text { trial }(n=22)\end{array}$ & $\begin{array}{l}\text { Twenty-two research } \\
\text { diagnostic criteria } \\
\text { (RDC) bipolar I }(n=15) \\
\text { and II }(n=7) \text { patients } \\
\text { (age }>18 \text { years); } \\
\text { absence of concomitant } \\
\text { serious physical illness; } \\
\text { adequate contraceptive } \\
\text { control; with presence } \\
\text { of at least one episode } \\
\text { of the illness in the last } \\
\text { six months; presence of } \\
\text { residual or } \\
\text { subsyndromal features } \\
\text { (YMRS }>6 \text { or HAM-D > } \\
\text { 12, and CGI-BP > 3); } \\
\text { presence of at least one } \\
\text { relapse during the } \\
\text { treatment with mood } \\
\text { stabilizers with serum } \\
\text { levels within } \\
\text { therapeutic range. }\end{array}$ & $\begin{array}{l}\text { Schedule for } \\
\text { Affective } \\
\text { Disorders and } \\
\text { Schizophrenia } \\
\text { (SADS), YMRS } \\
\text { and HAM-D } \\
\text { scores }\end{array}$ & $\begin{array}{l}\text { Add-on gabapentin were } \\
\text { increased by } 300 \mathrm{mg} / \text { day, } \\
\text { titrated to clinical response } \\
\text { or tolerance, up to a } \\
\text { maximum dose of } 2400 \\
\text { mg/day. The mean dose of } \\
\text { gabapentin was } 1310 \\
\mathrm{mg} / \text { day, within a range } \\
\text { from } 600 \text { to } 2400 \mathrm{mg} / \text { day. } \\
\text { The most common dose } \\
\text { prescribed was } 1200 \\
\text { mg/day. }\end{array}$ & $\begin{array}{l}\text { - Six patients (27.3\%) who did } \\
\text { not complete the study dropped } \\
\text { out for different reasons: four } \\
\text { de to lack of efficacy, one } \\
\text { because of intolerance (mild } \\
\text { rash) and another because of } \\
\text { noncompliance. } \\
-8 \text { patients improved as there } \\
\text { was a decrease of at least } 2 \\
\text { points in the CGI-BP, in the } \\
\text { other eight patients who } \\
\text { completed the study, a modest } \\
\text { improvement was observed in } \\
\text { three of them; four did not } \\
\text { show any therapeutic effects. } \\
- \text { The comparison of mean } \\
\text { scores in CGI-BP showed a } \\
\text { significant improvement in the } \\
\text { depression subscale that } \\
\text { decreased from } 4.5 \pm 1.2 \text { to } \\
2.9 \pm 1.5 \text { points (Wilcoxon } \\
Z=-3.1074, p<0.002), \text { taking } \\
\text { into account only patients who } \\
\text { completed the study. } \\
- \text { The improvement in the mania } \\
\text { subscale was not significant } \\
\text { (3.3 } \pm 1.1 \text { vs. } 2.9 \pm 1.0 ; \\
\text { Wilcoxon } Z=-1.5799, p=\text { NS). } \\
- \text { Most patients showed some } \\
\text { improvement in social } \\
\text { functioning and irritability. } \\
- \text { There were non-significant } \\
\text { differences in the efficacy of } \\
\text { gabapentin between bipolar I } \\
\text { and II patients, and between } \\
\text { rapid cyclers and } \\
\text { non-rapid cyclers. }\end{array}$ \\
\hline
\end{tabular}


Table 1. Cont.

\begin{tabular}{|c|c|c|c|c|c|}
\hline Author, Year & $\begin{array}{l}\text { Study Design } \\
(\mathbf{N})\end{array}$ & Study Population & $\begin{array}{l}\text { Clinical } \\
\text { Assessment or } \\
\text { Rating Tool(s) }\end{array}$ & Intervention(s) & Key Findings \\
\hline $\begin{array}{l}\text { Vieta et al., } \\
2006 \text { [32] }\end{array}$ & $\begin{array}{l}\text { Double-blind, } \\
\text { placebo- } \\
\text { controlled, } \\
\text { randomized } \\
\text { trial }(n=25)\end{array}$ & $\begin{array}{l}\text { Patients, } n=13 \text { in the } \\
\text { treatment group (mean } \\
\text { age } 46.2 \text { years) and } n= \\
12 \text { in the placebo group } \\
\text { (mean age } 47.6 \text { years), } \\
\text { diagnosed with bipolar } \\
\text { I or II according to } \\
\text { DSM-IV criteria and } \\
\text { were treated with any } \\
\text { standard mood } \\
\text { stabilizer in the last } \\
\text { year; two bipolar } \\
\text { episodes or more } \\
\text { during the last year; } \\
\text { CGI-BP scores equal or } \\
\text { greater than } 4 \text {; last } \\
\text { episode within past } 6 \\
\text { months; euthymic; } \\
\text { score of } 8 \text { or less on the } \\
\text { HAM-D and } 4 \text { or less } \\
\text { on the YMRS. }\end{array}$ & $\begin{array}{l}\text { CGI-BP, HAM-D, } \\
\text { HAM-A, PSQI } \\
\text { and YMRS }\end{array}$ & $\begin{array}{l}\text { Gabapentin dose was } 1200 \\
\text { mg/day and kept that way } \\
\text { unless there were emerging } \\
\text { symptoms, then it was } \\
\text { increased up to } 2400 \\
\text { mg/day and if there were } \\
\text { adverse events it would be } \\
\text { reduced to } 900 \mathrm{mg} / \text { day. }\end{array}$ & $\begin{array}{l}\text { - } 13 \text { subjects ( } 7 \text { from gabapentin } \\
\text { group and } 6 \text { from placebo } \\
\text { group) completed the study. } \\
\text { - Reasons for discontinuation in } \\
\text { the gabapentin group were due } \\
\text { to withdrawal to participate ( } n \\
=2) \text {, lack of efficacy }(n=2) \text {, } \\
\text { adverse events ( } n=1) \text { and other } \\
\text { reasons ( } n=1 \text { ). In the placebo } \\
\text { group, } 3 \text { no longer wanted to } \\
\text { participate, } 1 \text { had a lack of } \\
\text { efficacy and } 1 \text { had adverse } \\
\text { events and } 1 \text { (other reasons). } \\
\text { - The change in CGI-BP between } \\
\text { the groups were statistically } \\
\text { significant (gabapentin:-2.1, } \\
\text { Placebo: - } 0.6, p=0.0046 \text { ). } \\
\text { - No significant differences } \\
\text { between groups in YMRS, } \\
\text { HAM-D, HAM-A and } \\
\text { PSQI scores. } \\
\text { - PSQI- } 6 \text { subscale (use of } \\
\text { sleeping medication), the score } \\
\text { change at month } 12 \text { in the } \\
\text { gabapentin group was }-1.1 \text { and } \\
\text { placebo was }-0.6 \text { ( } p=0.0267 \text { ). }\end{array}$ \\
\hline $\begin{array}{l}\text { Wang et al., } \\
2002[33]\end{array}$ & $\begin{array}{l}\text { Open-label } \\
\text { trial }(n=22)\end{array}$ & $\begin{array}{l}\text { Outpatients ( } 10 \text { females } \\
\text { and } 12 \text { males, mean age } \\
38.4 \text { years); met } \\
\text { DSM-IV Criteria for } \\
\text { bipolar I or II disorder } \\
\text { by semistructured } \\
\text { clinical interview and } \\
\text { DSM-IV criteria for } \\
\text { major depressive } \\
\text { episode with a } 28 \text {-item } \\
\text { HAM-D score }>18 \text { at } \\
\text { screening }\end{array}$ & $\begin{array}{l}\text { 28-item HAM-D, } \\
\text { YMRS and CGI-S }\end{array}$ & $\begin{array}{l}\text { Adjunctive therapy of } \\
\text { gabapentin to stable doses } \\
\text { of mood stabilizers or } \\
\text { atypical antipsychotics, } \\
\text { initiated at } 300 \mathrm{mg} \text { at } \\
\text { bedtime and increased by } \\
300 \mathrm{mg} \text { every four nights } \\
\text { until symptom relief or } \\
\text { adverse effects were noted. } \\
\text { Final GBP dose was } \\
\text { clinically determined. } \\
\text { Maximum dose } 3600 \mathrm{mg} \\
\text { per day in divided doses } \\
\text { (range } 600 \mathrm{mg} \text { to } 3300 \mathrm{mg} \text { ). }\end{array}$ & $\begin{array}{l}\text { - There was a decrease in mean } \\
\text { HAM-D ratings from } 32.5(7.7) \\
\text { to } 16.5(12.8)(\mathrm{t}=8.11, \mathrm{df}=21, \\
p=<0.0001) . \\
\text { - Mean CGI-S decreased from } \\
4.4(0.9) \text { to } 3.0(1.7)(\mathrm{t}=5.2, \\
\mathrm{df}=21, p<0.0001) . \\
\text { - YMRS were unchanged. } \\
\text { - } 12 \text { of } 22 \text { patients were } \\
\text { responsive to treatment, with } \\
\text { mean HAM-D decreasing } 78 \% \\
\text { from } 27.9(6.2) \text { to } 6.2(4.5), \\
p<0.0001 .8 \text { of } 22 \text { patients were } \\
\text { remitted. In non-responders, } \\
\text { HAM-D decreased } 24 \% \text { from } \\
38.0(5.4) \text { to } 28.9(6.7), p=0.005 . \\
\text { - Mild to moderately depressed } \\
\text { patients (HAM-D less than } 35 \text { at } \\
\text { baseline) had a response rate of } \\
77 \% . \text { Severely depressed } \\
\text { patients (HAM-D equal to or } \\
\text { greater than } 35 \text { at baseline) had } \\
\text { a response rate of } 22 \% \text {. Mild to } \\
\text { moderately depressed patients } \\
\text { had their HAM-D decreased by } \\
\text { 16.7 (8.6). Severely depressed } \\
\text { patients had their HAM-D } \\
\text { decreased by } 15.0(10.7) \text {. } \\
\text { - Responders had longer bipolar } \\
\text { disorder illness duration } \\
\text { (23.3 (12.2) vs. } 12.9(9.8) \text { ). } \\
\text { - Final gabapentin dose was } \\
\text { higher in non-responders ( } 2085) \\
\text { than in responders }(1425) . \\
\text { - Gabapentin was generally well } \\
\text { tolerated. Mild sedation was } \\
\text { the most common adverse } \\
\text { effect in } 7 \text { patients. }\end{array}$ \\
\hline
\end{tabular}


Table 1. Cont

\begin{tabular}{|c|c|c|c|c|c|}
\hline Author, Year & $\begin{array}{c}\text { Study Design } \\
(\mathbf{N})\end{array}$ & Study Population & $\begin{array}{l}\text { Clinical } \\
\text { Assessment or } \\
\text { Rating Tool(s) }\end{array}$ & Intervention(s) & Key Findings \\
\hline $\begin{array}{l}\text { Young et al., } \\
1999 \text { [34] }\end{array}$ & $\begin{array}{l}\text { Open-label } \\
\text { trial }(n=37)\end{array}$ & $\begin{array}{l}\text { Outpatients ( } 12 \text { males } \\
\text { and } 23 \text { females; mean } \\
\text { age } 42.2 \text { years), } \\
\text { diagnosed with bipolar } \\
\text { disorder Type I or II, } \\
\text { based on the structured } \\
\text { clinical interview for } \\
\text { DSM-IV; in both } \\
\text { depressed and manic } \\
\text { phases. All treated } \\
\text { previously with and } \\
\text { failed to respond to at } \\
\text { least two mood } \\
\text { stabilizers. }\end{array}$ & $\begin{array}{l}\text { HAM-D and } \\
\text { YMRS }\end{array}$ & $\begin{array}{l}\text { Adjunctive gabapentin to } \\
\text { current treatment, dosed } 2 \\
\text { to } 3 \text { times a day, ranging } \\
\text { from } 300 \mathrm{mg} \text { /day to a } \\
\text { maximum of } 3600 \mathrm{mg} / \text { day } \\
\text { and a mean daily dose of } \\
1264 \mathrm{mg} \text { (SD: 136). }\end{array}$ & $\begin{array}{l}\text { - Those who were depressed at } \\
\text { the start of the study showed a } \\
\text { significant decrease in } \\
\text { depression symptoms } \\
(p<0.001) \text {. This improvement } \\
\text { was maintained over } 6 \text { months } \\
\text { in } 17 \text { patients. Significant } \\
\text { improvement in the global } \\
\text { assessment of functioning from } \\
\text { baseline to } 12 \text { weeks and } 24 \\
\text { weeks }(55+/-1.3 \text { to } 67+/- \\
2.9 \text { to } 67+/-3.6) \text {. } \\
\text { - In maniac patients, there was a } \\
\text { reduction in mania symptoms } \\
(p<0.001) \text { and maintained over } \\
6 \text { months. The manic group } \\
\text { showed nonsignificant } \\
\text { improvement in global } \\
\text { assessment of functioning. } \\
\text { - There was a significant overall } \\
\text { reduction in anxiety and mood } \\
\text { clusters }(p<0.001) \text {. } \\
\text { - The drug was well tolerated. } \\
\text { Side effects include: } \\
\text { constipation }(n=4), \text { dry mouth } \\
(n=6) \text {, trouble sleeping }(n=7) \text {, } \\
\text { daytime drowsiness }(n=8), \\
\text { anxiety }(n=9) \text {, blurred vision }(n \\
=5), \text { sexual difficulties }(n=9) \text {. }\end{array}$ \\
\hline
\end{tabular}

Abbreviations: BPRS, Brief Psychiatric Rating Scale; CGI-BP, Clinical Global Impression Scale modified for Bipolar illness; CGI-S, Clinical Global Impression of Severity; DSM, Diagnostic and Statistical Manual of Mental Disorders; HAM-A, Hamilton Rating Scale for Anxiety; HAM-D, Hamilton Rating Scale for Depression; ICD, International Statistical Classification of Diseases and Related Health Problems; PSQI, Pittsburgh Sleep Quality Index; SD, standard deviation; SIMD, semistructured interview for mood disorder; STAI, Spielberger State-Trait Anxiety Inventory; Young Mania Rating Scale, YMRS.3.1. Study Designs.

\section{Results}

Figure 1 detailed the study selection and identification process. A total of 1186 records were found from the database search, with 767 records marked ineligible by automated filters and 114 records removed as duplicates. A total of 286 articles were further excluded after title and abstract screening, and subsequently three articles were excluded after a full text review. Finally, a total of 19 studies were included for thematic analysis [19-37].

There were 18 studies that trialled gabapentin use in BD [16-28,30-34] and only one study on pregabalin [29]. With reference to Table 1, study designs were heterogenous with a total of 13 open-label trials [19,21-23,25,26,30-34,36,37] and six RCTs, which employed different treatment regimes from cross-over trials to fixed-dose trials. [20,24,27-29,35] Most of these trials had a generally high risk of bias, as seen in Table 2. Due to this heterogeneity in designs, it was challenging to discern the source of the therapeutic effect, making it difficult to attribute any observed benefit to solely gabapentin or pregabalin. A metaanalysis was not performed for these reasons. 
Table 2. Results of Cochrane Collaboration's tool for assessing risk of bias.

\begin{tabular}{|c|c|c|c|c|c|c|}
\hline Study (Author, Year) & $\begin{array}{c}\text { Sequence } \\
\text { Generation }\end{array}$ & $\begin{array}{l}\text { Allocation } \\
\text { Concealment }\end{array}$ & Blinding & $\begin{array}{c}\text { Incomplete } \\
\text { Outcome } \\
\text { Data }\end{array}$ & $\begin{array}{l}\text { Selective } \\
\text { Outcome } \\
\text { Reporting }\end{array}$ & $\begin{array}{l}\text { Other } \\
\text { Bias }\end{array}$ \\
\hline Altshuleret al., 1999 [16] & - & - & - & + & + & $?$ \\
\hline Astaneh et al., 2012 [17] & + & - & - & $?$ & $?$ & $?$ \\
\hline Cabras et al., 1999 [18] & - & - & - & + & $?$ & $?$ \\
\hline Carta et al., 2001 [19] & - & - & - & - & $?$ & $?$ \\
\hline Erfurth et al., 1998 [20] & - & - & - & $?$ & - & - \\
\hline Frye et al., 2000 [21] & + & $?$ & + & + & + & $?$ \\
\hline Mauri et al., 2001 [22] & - & - & - & + & $?$ & $?$ \\
\hline McElroy et al., 1997 [23] & - & - & - & - & $?$ & - \\
\hline Mokhber et al., 2008 [24] & $?$ & $?$ & + & $?$ & + & $?$ \\
\hline Obrocea et al., 2002 [25] & $?$ & $?$ & $?$ & + & + & $?$ \\
\hline Pande et al., 2000 [26] & $?$ & $?$ & $?$ & + & + & - \\
\hline Perugi et al., 1999 [27] & - & - & - & $?$ & + & $?$ \\
\hline Perugi et al., 2002 [28] & - & - & - & $?$ & + & $?$ \\
\hline Schaffer et al., 2013 [29] & - & - & - & $?$ & $?$ & $?$ \\
\hline Sokolski et al., 1999 [30] & - & - & - & + & $?$ & + \\
\hline Vieta et al., 2000 [31] & - & - & - & + & + & + \\
\hline Vieta et al., 2006 [32] & + & + & + & + & + & $?$ \\
\hline Wang et al., 2002 [33] & - & - & - & + & $?$ & $?$ \\
\hline Young et al., 1999 [34] & - & - & - & + & $?$ & $?$ \\
\hline
\end{tabular}

Key: + low risk of bias; - high risk of bias; ? unclear risk of bias.

\subsection{Intervention Type}

Most of the studies were adjunctive treatment trials: 12 of the included studies administered gabapentin as an adjunctive treatment [16-19,23,27,28,30-34]. One study administered pregabalin as an adjunctive treatment [29]. Three studies administered gabapentin as a monotherapy $[20,22,26]$ and another two studies employed a cross-over design with lamotrigine and placebo with a one-week washout period in between treatment segments [21,25]. Only one study administered gabapentin both as an add-on treatment and a monotherapy and compared the differences between these two experimental arms [20].

\subsection{Dosing Regimes}

The most common range of gabapentin dosing was 300 to $2400 \mathrm{mg} /$ day. The maximum daily dose was $4800 \mathrm{mg}$. It was reported by Sokolski et al. that most patients had attained therapeutic effectiveness at a $900 \mathrm{mg}$ dose even though the initial dose was $300 \mathrm{mg}$ [33]. For the sole study on pregabalin, the average dose for acute patients was $72 \mathrm{mg} /$ day [29]. 


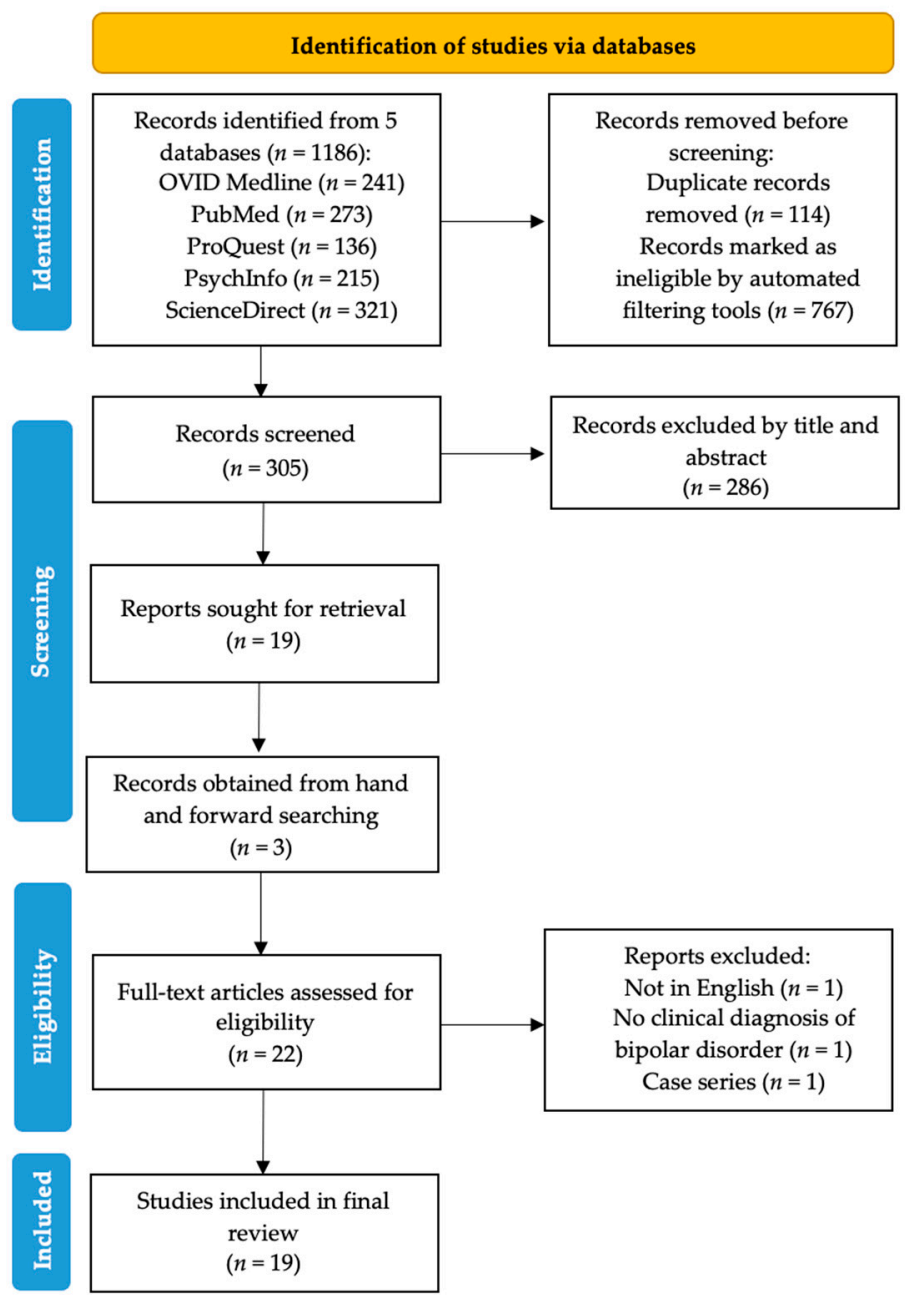

Figure 1. PRISMA flowchart showing the abstraction process.

\subsection{Clinical Assessment Tools}

There was a wide spectrum of scales used to assess symptom severity and treatment response across all 19 studies. With respect to the assessment of mania, ten studies utilized the YMRS, three studies utilized the BMRS while another three studies used the HAMA. The Clinical Global Impression Scale for use in Bipolar Illness (CGI-BP) was used in five studies while the CGI-S and CGI-C subscales were used in two and three studies respectively. The BPRS was used in three studies, while the STAI was used in two studies. The AIRP, MMPI-2, SADS and ISS were each employed by one study.

\subsection{Treatment Efficacy and Side Effects}

Five studies reported a significant reduction in severity scores for mania post gabapentin therapy $[20,23,27,29,33]$. Among these five trials, it was Pande et al.'s 2000 study that reported a lower decrease in YMRS scores for the gabapentin experimental arm as compared to the placebo arm [29].

Seven studies reported a significant reduction in severity scores for depression, with gabapentin therapy. Four studies reported significant improvement in bipolar severity as measured by BPRS, AIRP and CGI-BP. Sedation was the most common side effect as reported in six studies $[19,21,23,26,33,36]$.

Of note is the difference in treatment efficacy noted by Erfurth et al.'s 1998 study that compared adjunctive gabapentin treatment with gabapentin monotherapy within the same time period [20]. For the adjunctive group, all six patients had a significant decrease in their BMRS scores, while for the monotherapy group, four out of eight patients dropped 
out due to treatment insufficiency. There was a significant decrease in BMRS scores for the remaining four patients in the monotherapy group.

\section{Discussion}

Overall, the studies show that gabapentin and its related drug pregabalin do not have significant clinical efficacy as either monotherapy or adjunctive therapy for patients with BD. Multiple RCTs have found that gabapentin and pregabalin are ineffective for acute mania, with only small open-label trials to support its potential adjunctive role. There may be an adjunctive role for patients in a depressed state or with comorbid anxiety or substance use issues.

As most studies were adjunctive treatment trials, it remains unclear if the positive therapeutic response observed was primarily the result of the drug that was added to pre-existing agents (usually stable doses of mood stabilizers or antipsychotics), or the result of a synergistic effect. Furthermore, in open trials, without appropriate controls, it is also unclear if the observed effect is due to spontaneous remission of symptoms given the natural history of $\mathrm{BD}$. While crossover trial designs have a key drawback of carryover effects although these tend to be reduced with a washout period that lasts a week or two between treatment segments [38].

The existence of a single trial that investigated the use of pregabalin in BD limits any strong conclusions. Pregabalin was developed as a successor to gabapentin; it was formally approved in 2004, as compared to gabapentin, which has been in use since 1994 [39]. The pharmacodynamic action of pregabalin is similar to gabapentin, characterized by its binding to the $\alpha 2-\delta$ subunit on voltage-gated calcium channels. Pregabalin is structurally similar to the inhibitory neurotransmitter $\gamma$-aminobutyric acid (GABA) although it does not bind to GABA receptors nor does it impact the uptake or breakdown of GABA. While various pharmacologic effects have been reported, pregabalin essentially acts to reduce the release of excitatory neurotransmitters such as substance $P$ and glutamate, which have been linked to the pathogenesis of bipolar disorders.

Gabapentin and pregabalin are probably not effective for depressive state but may improve some subscales, such as irritability, social withdrawal or anxiety. They may have benefits for anxiety symptoms as do most GABAergic agents and also potential utility for bipolar individuals with comorbid substance use disorders. Its sedating effects probably can help alleviate insomnia and it is generally well-tolerated in terms of side-effect profile.

Bipolar illness is a life-course disorder; its chronic, enduring nature with interspersed periods of elation, irritability and depression usually demands maintenance treatment [10]. It was interesting to note that in an open-label trial, $39.5 \%(n=17)$ of the patients maintained symptomatic remission over a period of 4 to 18 months on adjunctive gabapentin [28]. However, as therapeutic strategies shift towards long-term horizons, there are increasing concerns regarding dependence with long-term use. Relative to lithium, the use of gabapentin is significantly associated with a doubling of the risk of suicidality in patients diagnosed with BD [40].

Potential issues with dependence and also elevated mood switch belie the use of gabapentinoids. Even though gabapentin and pregabalin are considered as a treatment option for alcohol and substance abuse, there are numerous published case reports and case series documenting abuse, dependence, and withdrawal effects [41]. Caution must also be exercised by monitoring renal function due to the excretion of these drugs via renal pathways.

Another limitation of current evidence pertains to the different clinical assessment tools used to evaluate BD symptom severity and treatment response. BD is in itself a complex disorder, presenting with heterogeneous symptoms ranging from depression, hypomania to mixed states and even psychosis [42]. Many rating tools have been used in the clinical assessment of BD patients; however, they all have certain weaknesses [43]. For example, the usual CGI is a global measure of improvement in functioning, without rating scales specific for hypomanic/manic and depressive symptoms, compared to the Young 
Mania Rating Scale (YMRS), the Bech-Rafaelsen Mania Rating Scale (BMRS) [44], or the modified CGI-BP [45]. When studying patients with rapid-cycling states, multiple scales should be used to more adequately evaluate response [24]. Importantly, the contemporary redefinition of the clinical hallmarks of bipolar disorder (with activation as the most common dimension in mania), also necessitates the revisiting of new scales that apportion greater emphasis to activity or energy levels in this patient population $[46,47]$.

\section{Conclusions}

In conclusion, there is a lack of rigorous evidence to support the clinical efficacy of gabapentin and pregabalin for the treatment of acute mania or acutely depressed BD patients. It should not be used as monotherapy in the short- or long-term period, however, as adjunctive therapy, its effects on the long-term outcomes of BD remain to be elucidated.

Author Contributions: Conceptualization, Q.X.N. and K.T.C.; Data Curation, M.X.H., S.E.T., C.Y.L.Y. and Y.L.L.; Formal Analysis, Q.X.N., M.X.H., S.E.T., C.Y.L.Y. and Y.L.L.; Investigation, Q.X.N., Y.L.L. and K.T.C.; Methodology, Q.X.N., M.X.H., S.E.T., C.Y.L.Y., Y.L.L. and K.T.C.; Resources, Q.X.N.; Software, Q.X.N. and M.X.H.; Supervision, K.T.C.; Writing-Original Draft, Q.X.N., M.X.H., S.E.T., C.Y.L.Y., Y.L.L. and K.T.C.; Writing—Review and Editing, Q.X.N., M.X.H., S.E.T., C.Y.L.Y., Y.L.L. and K.T.C. All authors have read and agreed to the published version of the manuscript.

Funding: This research received no external funding.

Institutional Review Board Statement: Not applicable.

Informed Consent Statement: Not applicable.

Data Availability Statement: Data sharing not applicable.

Conflicts of Interest: The authors declare no conflict of interest.

\section{References}

1. Grande, I.; Berk, M.; Birmaher, B.; Vieta, E. Bipolar disorder. Lancet 2016, 387, 1561-1572. [CrossRef]

2. Merikangas, K.R.; Lamers, F. The 'true'prevalence of bipolar II disorder. Curr. Opin. Psychiatry 2012, 25, 19-23. [CrossRef] [PubMed]

3. Benazzi, F. Bipolar disorder-Focus on bipolar II disorder and mixed depression. Lancet 2007, 369, 935-945. [CrossRef]

4. Schaffer, A.; Isometsä, E.T.; Tondo, L.; Doris, H.M.; Turecki, G.; Reis, C.; Cassidy, F.; Sinyor, M.; Azorin, J.M.; Kessing, L.V. International Society for Bipolar Disorders Task Force on Suicide: Meta-analyses and meta-regression of correlates of suicide attempts and suicide deaths in bipolar disorder. Bipolar Disord. 2015, 17, 1-16. [CrossRef] [PubMed]

5. López-Muñoz, F.; Shen, W.W.; D’ocon, P.; Romero, A.; Álamo, C. A history of the pharmacological treatment of bipolar disorder. Int. J. Mol. Sci. 2018, 19, 2143. [CrossRef]

6. Serafini, G.; Gonda, X.; Pompili, M.; Rihmer, Z.; Amore, M.; Engel-Yeger, B. The relationship between sensory processing patterns, alexithymia, traumatic childhood experiences, and quality of life among patients with unipolar and bipolar disorders. Child Abus. Negl. 2016, 62, 39-50. [CrossRef] [PubMed]

7. Kleine-Budde, K.; Touil, E.; Moock, J.; Bramesfeld, A.; Kawohl, W.; Rössler, W. Cost of illness for bipolar disorder: A systematic review of the economic burden. Bipolar Disord. 2014, 16, 337-353. [CrossRef]

8. Cloutier, M.; Greene, M.; Guerin, A.; Touya, M.; Wu, E. The economic burden of bipolar I disorder in the United States in 2015. J. Affect. Disord. 2018, 226, 45-51. [CrossRef]

9. Perlis, R.H.; Ostacher, M.J.; Patel, J.K.; Marangell, L.B.; Zhang, H.; Wisniewski, S.R.; Ketter, T.A.; Miklowitz, D.J.; Otto, M.W.; Gyulai, L. Predictors of recurrence in bipolar disorder: Primary outcomes from the Systematic Treatment Enhancement Program for Bipolar Disorder (STEP-BD). Am. J. Psychiatry 2006, 163, 217-224. [CrossRef]

10. Yatham, L.N.; Kennedy, S.H.; Parikh, S.V.; Schaffer, A.; Bond, D.J.; Frey, B.N.; Sharma, V.; Goldstein, B.I.; Rej, S.; Beaulieu, S. Canadian Network for Mood and Anxiety Treatments (CANMAT) and International Society for Bipolar Disorders (ISBD) 2018 guidelines for the management of patients with bipolar disorder. Bipolar Disord. 2018, 20, 97-170. [CrossRef]

11. Amerio, A.; Russo, D.; Miletto, N.; Aguglia, A.; Costanza, A.; Benatti, B.; Odone, A.; Barroilhet, S.A.; Brakoulias, V.; Dell'Osso, B. Polypharmacy as maintenance treatment in bipolar illness: A systematic review. Acta Psychiatr. Scand. 2021. [CrossRef]

12. Yamawaki, S.; Kagaya, A.; Tawara, Y.; Inagaki, M. Intracellular calcium signaling systems in the pathophysiology of affective disorders. Life Sci. 1998, 62, 1665-1670. [CrossRef]

13. Gee, N.S.; Brown, J.P.; Dissanayake, V.U.; Offord, J.; Thurlow, R.; Woodruff, G.N. The novel anticonvulsant drug, gabapentin (Neurontin), binds to the subunit of a calcium channel. J. Biol. Chem. 1996, 271, 5768-5776. [CrossRef] 
14. Dooley, D.J.; Donovan, C.M.; Meder, W.P.; Whetzel, S.Z. Preferential action of gabapentin and pregabalin at P/Q-type voltagesensitive calcium channels: Inhibition of $\mathrm{K}+$-evoked $[3 \mathrm{H}]$-norepinephrine release from rat neocortical slices. Synapse 2002, 45, 171-190. [CrossRef]

15. Sills, G.J. The mechanisms of action of gabapentin and pregabalin. Curr. Opin. Pharmacol. 2006, 6, 108-113. [CrossRef]

16. Houghton, K.T.; Forrest, A.; Awad, A.; Atkinson, L.Z.; Stockton, S.; Harrison, P.J.; Geddes, J.R.; Cipriani, A. Biological rationale and potential clinical use of gabapentin and pregabalin in bipolar disorder, insomnia and anxiety: Protocol for a systematic review and meta-analysis. BMJ Open 2017, 7, e013433. [CrossRef]

17. Page, M.J.; McKenzie, J.E.; Bossuyt, P.M.; Boutron, I.; Hoffmann, T.C.; Mulrow, C.D.; Shamseer, L.; Tetzlaff, J.M.; Akl, E.A.; Brennan, S.E. The PRISMA 2020 statement: An updated guideline for reporting systematic reviews. BMJ 2021, 372. [CrossRef]

18. Higgins, J.P.; Altman, D.G.; Gøtzsche, P.C.; Jüni, P.; Moher, D.; Oxman, A.D.; Savović, J.; Schulz, K.F.; Weeks, L.; Sterne, J.A. The Cochrane Collaboration's tool for assessing risk of bias in randomised trials. BMJ 2011, 343. [CrossRef] [PubMed]

19. Altshuler, L.L.; Keck, P.E., Jr.; McElroy, S.L.; Suppes, T.; Brown, E.S.; Denicoff, K.; Frye, M.; Gitlin, M.; Hwang, S.; Goodman, R.; et al. Gabapentin in the acute treatment of refractory bipolar disorder. Bipolar Disord. 1999, 1, 61-65. [CrossRef] [PubMed]

20. Astaneh, A.N.; Rezaei, O. Adjunctive treatment with gabapentin in bipolar patients during acute mania. Int. J. Psychiatry Med. 2012, 43, 261-271. [CrossRef]

21. Cabras, P.L.; Hardoy, J.; Hardoy, M.C.; Carta, M.G. Clinical experience with gabapentin in patients with bipolar or schizoaffective disorder: Results of an open-label study. J. Clin. Psychiatry 1999, 60, 245-248. [CrossRef]

22. Carta, M.G.; Hardoy, M.C.; Dessi, I.; Hardoy, M.J.; Carpiniello, B. Adjunctive gabapentin in patients with intellectual disability and bipolar spectrum disorders. J. Intellect. Disabil. Res. 2001, 45, 139-145. [CrossRef]

23. Erfurth, A.; Kammerer, C.; Grunze, H.; Normann, C.; Walden, J. An open label study of gabapentin in the treatment of acute mania. J. Psychiatr. Res. 1998, 32, 261-264. [CrossRef]

24. Frye, M.A.; Ketter, T.A.; Kimbrell, T.A.; Dunn, R.T.; Speer, A.M.; Osuch, E.A.; Luckenbaugh, D.A.; Cora-Ocatelli, G.; Leverich, G.S.; Post, R.M. A placebo-controlled study of lamotrigine and gabapentin monotherapy in refractory mood disorders. J. Clin. Psychopharmacol. 2000, 20, 607-614. [CrossRef] [PubMed]

25. Mauri, M.C.; Laini, V.; Scalvini, M.E.; Omboni, A.; Ferrari, V.M.; Clemente, A.; Salvi, V.; Cerveri, G. Gabapentin and the prophylaxis of bipolar disorders in patients intolerant to lithium. Clin. Drug Investig. 2001, 21, 169-174. [CrossRef] [PubMed]

26. McElroy, S.L.; Soutullo, C.A.; Keck, P.E., Jr.; Kmetz, G.F. A pilot trial of adjunctive gabapentin in the treatment of bipolar disorder. Ann. Clin. Psychiatry 1997, 9, 99-103. [CrossRef]

27. Mokhber, N.; Lane, C.J.; Azarpazhooh, M.R.; Salari, E.; Fayazi, R.; Shakeri, M.T.; Young, A.H. Anticonvulsant treatments of dysphoric mania: A trial of gabapentin, lamotrigine and carbamazepine in Iran. Neuropsychiatr. Dis. Treat. 2008, 4, 227-234. [PubMed]

28. Obrocea, G.V.; Dunn, R.M.; Frye, M.A.; Ketter, T.A.; Luckenbaugh, D.A.; Leverich, G.S.; Speer, A.M.; Osuch, E.A.; Jajodia, K.; Post, R.M. Clinical predictors of response to lamotrigine and gabapentin monotherapy in refractory affective disorders. Biol. Psychiatry 2002, 51, 253-260. [CrossRef]

29. Pande, A.C.; Crockatt, J.G.; Janney, C.A.; Werth, J.L.; Tsaroucha, G. Gabapentin in bipolar disorder: A placebo-controlled trial of adjunctive therapy. Gabapentin Bipolar Disorder Study Group. Bipolar Disord. 2000, 2, 249-255. [CrossRef]

30. Perugi, G.; Toni, C.; Frare, F.; Ruffolo, G.; Moretti, L.; Torti, C.; Akiskal, H.S. Effectiveness of adjunctive gabapentin in resistant bipolar disorder: Is it due to anxious-alcohol abuse comorbidity? J. Clin. Psychopharmacol. 2002, 22, 584-591. [CrossRef]

31. Perugi, G.; Toni, C.; Ruffolo, G.; Sartini, S.; Simonini, E.; Akiskal, H. Clinical experience using adjunctive gabapentin in treatment-resistant bipolar mixed states. Pharmacopsychiatry 1999, 32, 136-141. [CrossRef] [PubMed]

32. Schaffer, L.C.; Schaffer, C.B.; Miller, A.R.; Manley, J.L.; Piekut, J.A.; Nordahl, T.E. An open trial of pregabalin as an acute and maintenance adjunctive treatment for outpatients with treatment resistant bipolar disorder. J. Affect. Disord. 2013, 147, 407-410. [CrossRef]

33. Sokolski, K.N.; Green, C.; Maris, D.E.; DeMet, E.M. Gabapentin as an adjunct to standard mood stabilizers in outpatients with mixed bipolar symptomatology. Ann. Clin. Psychiatry Off. J. Am. Acad. Clin. Psychiatr. 1999, 11, 217-222. [CrossRef]

34. Vieta, E.; Martinez-Aran, A.; Nieto, E.; Colom, F.; Reinares, M.; Benabarre, A.; Gasto, C. Adjunctive gabapentin treatment of bipolar disorder. Eur. Psychiatry J. Assoc. Eur. Psychiatr. 2000, 15, 433-437. [CrossRef]

35. Vieta, E.; Manuel Goikolea, J.; Martínez-Arán, A.; Comes, M.; Verger, K.; Masramon, X.; Sanchez-Moreno, J.; Colom, F. A double-blind, randomized, placebo-controlled, prophylaxis study of adjunctive gabapentin for bipolar disorder. J. Clin. Psychiatry 2006, 67, 473-477. [CrossRef]

36. Wang, P.W.; Santosa, C.; Schumacher, M.; Winsberg, M.E.; Strong, C.; Ketter, T.A. Gabapentin augmentation therapy in bipolar depression. Bipolar Disord. 2002, 4, 296-301. [CrossRef]

37. Young, L.T.; Robb, J.C.; Hasey, G.M.; MacQueen, G.M.; Siotis, I.P.; Marriott, M.; Joffe, R.T. Gabapentin as an adjunctive treatment in bipolar disorder. J. Affect. Disord. 1999, 55, 73-77. [CrossRef]

38. Post, R.M.; Luckenbaugh, D.A. Unique design issues in clinical trials of patients with bipolar affective disorder. J. Psychiatr. Res. 2003, 37, 61-73. [CrossRef]

39. Driot, D.; Jouanjus, E.; Oustric, S.; Dupouy, J.; Lapeyre-Mestre, M. Patterns of gabapentin and pregabalin use and misuse: Results of a population-based cohort study in France. Br. J. Clin. Pharmacol. 2019, 85, 1260-1269. [CrossRef] 
40. Leith, W.M.; Lambert, W.E.; Boehnlein, J.K.; Freeman, M.D. The association between gabapentin and suicidality in bipolar patients. Int. Clin. Psychopharmacol. 2019, 34, 27-32. [CrossRef]

41. Mersfelder, T.L.; Nichols, W.H. Gabapentin: Abuse, dependence, and withdrawal. Ann. Pharmacother. 2016, 50, 229-233. [CrossRef] [PubMed]

42. Ng, Q.X.; Lim, D.Y.; Chee, K.T. Reimagining the spectrum of affective disorders. Bipolar Disord. 2020, 22, 638-639. [CrossRef] [PubMed]

43. Picardi, A. Rating scales in bipolar disorder. Curr. Opin. Psychiatry 2009, 22, 42-49. [CrossRef]

44. Miller, C.J.; Johnson, S.L.; Eisner, L. Assessment tools for adult bipolar disorder. Clin. Psychol. Sci. Pract. 2009, 16, 188. [CrossRef] [PubMed]

45. Spearing, M.K.; Post, R.M.; Leverich, G.S.; Brandt, D.; Nolen, W. Modification of the Clinical Global Impressions (CGI) Scale for use in bipolar illness (BP): The CGI-BP. Psychiatry Res. 1997, 73, 159-171. [CrossRef]

46. Scott, J.; Murray, G.; Henry, C.; Morken, G.; Scott, E.; Angst, J.; Merikangas, K.R.; Hickie, I.B. Activation in bipolar disorders: A systematic review. JAMA Psychiatry 2017, 74, 189-196. [CrossRef] [PubMed]

47. Scott, J.; Murray, G. Are rating scales for bipolar disorders fit for purpose? Br. J. Psychiatry 2018, 213, 627-629. [CrossRef] 